\title{
Temperature and pressure gas geoindicators at the Solfatara fumaroles (Campi Flegrei)
}

\author{
Giovanni Chiodini ${ }^{1,{ }^{\star}}$, Rosario Avino ${ }^{1}$, Stefano Caliro ${ }^{1}$, Carmine Minopoli ${ }^{1}$ \\ ${ }^{1}$ Istituto Nazionale di Geofisica e Vulcanologia, sezione di Napoli, Osservatorio Vesuviano, Naples, Italy
}

\author{
Article history \\ Received December 21, 2010; accepted March 3, 2011. \\ Subject classification: \\ Solfatara, Campi Flegrei, Caldera, Gas equilibria.
}

\section{ABSTRACT}

Long time series of fluid pressure and temperature within a hydrothermal system feeding the Solfatara fumaroles are investigated here, on the basis of the chemical equilibria within the $\mathrm{CO}_{2}-\mathrm{H}_{2} \mathrm{O}-\mathrm{H}_{2}-\mathrm{CO}$ gas system. The Pisciarelli fumarole external to Solfatara crater shows an annual cycle of CO contents that indicates the occurrence of shallow secondary processes that mask the deep signals. In contrast, the Bocca Grande and Bocca Nova fumaroles located inside Solfatara crater do not show evidence of secondary processes, and their compositional variations are linked to the temperature-pressure changes within the hydrothermal system. The agreement between geochemical signals and the ground movements of the area (bradyseismic phenomena) suggests a direct relationship between the pressurization process and the ground uplift. Since 2007, the gas geoindicators have indicated pressurization of the system, which is most probably caused by the arrival of deep gases with high $\mathrm{CO}_{2}$ contents in the shallow parts of the hydrothermal system. This pressurization process causes critical conditions in the hydrothermal system, as highlighted by the increase in the fumarole temperature, the opening of new vents, and the localized seismic activity. If the pressurization process continues with time, it is not possible to rule out the occurrence of phreatic explosions.

\section{Introduction}

Solfatara fumaroles are located within the homonymous crater in the center of the Campi Flegrei caldera (Figure 1), which is a very dangerous volcanic area because it includes part of the city of Napoli (Naples), the town of Pozzuoli, and numerous densely inhabited villages. The area was affected in the past by numerous large explosive eruptions [Orsi et al. 1996], the last of which occurred in 1538 at Monte Nuovo. This eruption followed a period of ground uplift, which suddenly interrupted a secular subsidence [Dvorak and Mastrolorenzo 1991, Troise et al. 2007], which continued with the same rate after the eruption. A new uplift started in 1950 and reached a maximum of about $4 \mathrm{~m}$ in 1985 near the town of Pozzuoli [Del Gaudio et al. 2010]. This process occurred during three major unrest periods (bradyseisms), the first in
1950-1952, the second in 1969-1972, and the third in 1982-1984 [Barberi et al. 1984, Del Gaudio et al. 2010]. In addition, four "mini" uplift periods occurred in 1989, 1994, 2000 and 2006. All of the uplift periods in this area were accompanied by seismicity, and in particular, many thousands of earthquakes occurred during the two major crises in 1969-1972 and in 1982-1984. Since the last main bradyseism of 1982-1984, the general trend of ground motion showed a subsidence period until 2004-2005, when the soil started to uplift with a relatively low rate of $\sim 1.0-1.5 \mathrm{~cm} \mathrm{a}^{-1}$.

This study is aimed to determine whether variations in the temperature-pressure (T-P) conditions of the hydrothermal system feeding the Solfatara fumaroles accompanied this oscillating ground motion of Campi Flegrei. Here, we analyze long time series (from 1998 to 2010) of the chemical compositions of the fumaroles of the Solfatara of Pozzuoli, focusing on the reactive gas species (mainly hydrogen and carbon monoxide) that have been recognized by previous studies as geoindicators of the T-P conditions of hydrothermal systems [Giggenbach 1987, Chiodini and Cioni 1989, Chiodini and Marini 1998].

\section{Analytical methods}

The three main fumaroles of Solfatara (Bocca Grande [BG], Bocca Nova [BN] and Pisciarelli; Figure 1) have been routinely analyzed for their chemical composition by the Geochemistry Laboratory of the Istituto Nazionale di Geofisica e Vulcanologia (INGV) - Osservatorio Vesuviano since 1998. This dataset, which consists of 348 samples, is reported in the electronic Annex 1.

For the determination of the major gas species, fumarolic gases were collected in under-vacuum flasks that contained a $4 \mathrm{~N} \mathrm{NaOH}$ solution [Giggenbach 1975, Giggenbach and Gouguel 1989]. The condensates of water vapor and noncondensable gases were sampled by passing the fumarolic gases through a condenser cooled to $20{ }^{\circ} \mathrm{C}$ to $30{ }^{\circ} \mathrm{C}$ by water. The gas constituents were analyzed following the methods 


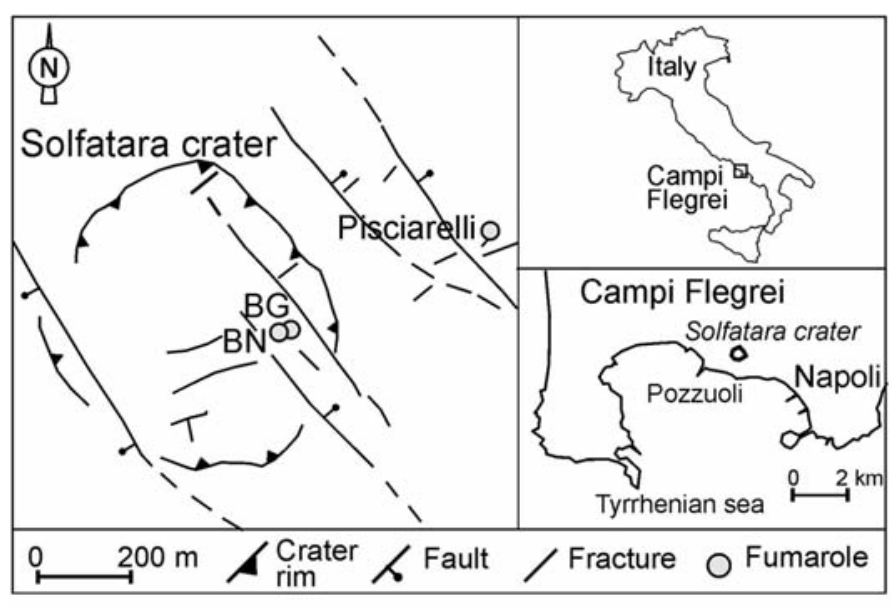

Figure 1. Location map and main geological features of the Solfatara crater, showing the Bocca Grande (BG), Bocca Nuova (BN) and Pisciarelli fumaroles.

of Cioni and Corazza [1981], modified for the analysis of He, $\mathrm{Ar}, \mathrm{O}_{2}, \mathrm{~N}_{2}, \mathrm{H}_{2}$ and $\mathrm{CH}_{4}$. The chemical compositions of the non-absorbed gases that were mainly present in the headspace over the $\mathrm{NaOH}$ solution were also measured, by gas chromatography using a thermal conductivity detector, through a single injection onto two molecular-sieve columns (MS $5 \AA$ capillary, $30 \mathrm{~m} \times 0.53 \mathrm{~mm} \times 50 \mathrm{~m}$; He and Ar as carrier gases). The $\mathrm{CO}_{2}$ and sulfur species absorbed in the alkaline solution were analyzed after oxidation via $\mathrm{H}_{2} \mathrm{O}_{2}$, by acid-base titration and ion chromatography, respectively (analytical error, $\pm 3 \%$ ). CO was analyzed on dry gas samples by gas chromatographic separation with a MS $5 \AA^{\circ} 1 / 8^{\prime} \times 50^{\prime}$ column (He as carrier gas), coupled with a high-sensitivity reduced gas detector $(\mathrm{HgO})$.

\section{Origin of the Solfatara fumaroles}

The Solfatara crater is located near the area of maximum ground uplift and of the recurrent earthquakes, and it is affected by an intense process of diffuse soil degassing and fumarolic activity. The total output of hydrothermal $\mathrm{CO}_{2}$ of $\sim 1500 \mathrm{t} \mathrm{d}^{-1}$ from the diffuse degassing processes was measured in December 1998 and in July 2000 [Chiodini et al. 2001, Cardellini et al. 2003]. According to Chiodini et al. [2001], the thermal energy release associated with the Solfatara gas emission $(\sim 100 \mathrm{MW})$ is the most important term in the energy balance of the whole of the Campi Flegrei caldera, as this is: (i) orders of magnitude greater than the elastic energy released during the seismic crises; (ii) higher than the energy associated with the ground deformation; and (iii) $\sim 10$-fold greater than the conductive heat flux over the entire caldera.

The fumaroles discharge at variable temperatures (from $95{ }^{\circ} \mathrm{C}$ to $165^{\circ} \mathrm{C}$ ), as mixtures of $\mathrm{H}_{2} \mathrm{O}$ and $\mathrm{CO}_{2}$ with minor amounts of $\mathrm{H}_{2} \mathrm{~S}, \mathrm{~N}_{2}, \mathrm{H}_{2}$ and $\mathrm{CH}_{4}$ (see Annex 1).

Geochemical studies of this hydrothermal system began in the early 1980's. A conceptual geochemical model of the system was first proposed by Cioni et al. [1984], and then refined by Cioni et al. [1989], Chiodini et al. [1992, 1996], Chiodini and Marini [1998], and Chiodini et al. [2000, 2001]. Furthermore, on the basis of a large dataset of chemical and isotopic compositions, Caliro et al. [2007] investigated the origin of the fumarolic fluids, and they proposed a more comprehensive geochemical model. According to Caliro et al. [2007], the system is fed by a mixture between fluids degassed from a magma body and the vapor generated at high temperatures $\left(\sim 360{ }^{\circ} \mathrm{C}\right)$ by the vaporization of hydrothermal liquids of meteoric origin (Figure 2). The mixing process appears to occur at the base of the hydrothermal system, where a plume is formed that is mainly composed of a gas phase that migrates towards the surface. According to physical simulations [Chiodini et al. 2003, Todesco et al. 2003], pulses of the magmatic source that arise from magma degassing episodes cause sudden increases in the mass of the fluids stored in the hydrothermal system; this is coupled with fluid pressurization, which triggers the volcanic unrest periods that periodically affect this area.

In the following sections, we will consider in detail whether there are any geochemical sign of fluid pressure variations within the hydrothermal system, on the basis of the chemical equilibria within this $\mathrm{CO}_{2}-\mathrm{H}_{2} \mathrm{O}-\mathrm{CH}_{4}-\mathrm{H}_{2}-\mathrm{CO}$ gas system.

\section{The $\mathrm{CO}_{2}-\mathrm{H}_{2} \mathrm{O}-\mathrm{CH}_{4}-\mathrm{H}_{2}-\mathrm{CO}$ gas equilibria}

The hydrothermal gas equilibria in this $\mathrm{CO}_{2}-\mathrm{H}_{2} \mathrm{O}-\mathrm{CH}_{4}$ $\mathrm{H}_{2}$-CO system were reviewed by Chiodini and Marini [1998]. They proposed a method that consists of the comparison of the analytical data with the compositions of both the equilibrium vapor and the equilibrium liquid phases, and of the vapor phases separated in a single-step from the equilibrium liquids at varying temperatures. In particular, the formation reactions of $\mathrm{CO}, \mathrm{H}_{2}$ and $\mathrm{CH}_{4}$ (Equations 1, 2 and 3, respectively) were combined to obtain two reactions (Equations 4 and 5), the equilibrium constants of which are independent of the oxygen fugacity.

$$
\begin{gathered}
\mathrm{CO}_{2}=\mathrm{CO}+\frac{1}{2} \mathrm{O}_{2} \\
\mathrm{H}_{2} \mathrm{O}=\mathrm{H}_{2}+1 / 2 \mathrm{O}_{2} \\
\mathrm{CO}_{2}+2 \mathrm{H}_{2} \mathrm{O}=\mathrm{CH}_{4}+2 \mathrm{O}_{2} \\
\mathrm{CO}_{2}+\mathrm{H}_{2}=\mathrm{H}_{2} \mathrm{O}+\mathrm{CO} \\
3 \mathrm{CO}_{2}+\mathrm{CH}_{4}=2 \mathrm{H}_{2} \mathrm{O}+4 \mathrm{CO}
\end{gathered}
$$

For gas phases that are largely made up of water vapor, the ratios of the fugacity coefficients $\Gamma \mathrm{H}_{2} / \Gamma \mathrm{H}_{2} \mathrm{O}$, $\Gamma \mathrm{CO} / \Gamma \mathrm{CO}_{2}$ and $\Gamma \mathrm{CH}_{4} / \Gamma \mathrm{CO}_{2}$, do not deviate significantly from 1.0 in the typical $\mathrm{P}-\mathrm{T}$ range of hydrothermal systems, as $100{ }^{\circ} \mathrm{C}$ to $374{ }^{\circ} \mathrm{C}$ and 1 bar to 220 bar [Chiodini and Marini 
1998, and references therein]. Therefore, the temperature dependence of the equilibrium constants of Equations (4) and (5) can be expressed as functions of the ratios of the mole fractions in the vapor phase, the Xi values, as:

$$
\begin{gathered}
\log \left(\mathrm{X}_{\mathrm{H} 2 \mathrm{O}} / \mathrm{X}_{\mathrm{H} 2}\right)+\log \left(\mathrm{X}_{\mathrm{CO}} / \mathrm{X}_{\mathrm{CO} 2}\right)= \\
=\mathrm{L}_{1}=2.485-2248 / \mathrm{TK}
\end{gathered}
$$

and

$$
\begin{gathered}
3 \log \left(\mathrm{X}_{\mathrm{CO}} / \mathrm{X}_{\mathrm{CO} 2}\right)+\log \left(\mathrm{X}_{\mathrm{CO}} / \mathrm{X}_{\mathrm{CH} 4}\right)= \\
=\mathrm{L}_{2}=19.605-17813 / \mathrm{TK},
\end{gathered}
$$

where TK is the absolute temperature. In Equation (7), the water fugacity has been assumed to be fixed, by the presence of the liquid $\left(\log \mathrm{f}_{\mathrm{H} 2 \mathrm{O}}=5.510-2048 / \mathrm{TK}\right)$ [Giggenbach 1980].

The relations of Equations (6) and (7) are then used to compute the theoretical $\mathrm{L}_{1}$ and $\mathrm{L}_{2}$ values for the equilibrium vapor phases (Figure 3, "vapor" line), and considering the corresponding vapor-liquid distribution coefficients for the equilibrium liquid phases (Figure 3, "liquid" line) and for the vapor phases that are separated in a single step from the equilibrium liquids at the varying temperatures (Figure 3 , "SSVS" lines; see Chiodini and Marini [1998] for details of the calculations). Figure 3 compares these theoretical compositions with the $\mathrm{L}_{1}$ and $\mathrm{L}_{2}$ values measured at the Solfatara fumaroles. The analytical values fall outside the field of the vapors separated by the liquid, i.e. outside the field delimited by the "vapor" and "liquid" lines. This behavior was originally interpreted as being caused by the presence of superheated vapor, at temperatures of $200{ }^{\circ} \mathrm{C}$ to $240{ }^{\circ} \mathrm{C}$, the theoretical compositions of which fall to the left of the "vapor" line in Figure 3 [Chiodini and Marini 1998]. However, more recently Caliro et al. [2007] studied a larger dataset, and based on their new ${ }^{13} \mathrm{C}$ data of the $\mathrm{CO}_{2}-\mathrm{CH}_{4}$ couple, they suggested a different interpretation. By using fractionation factors from Horita [2001], the $\mathrm{CO}_{2}-\mathrm{CH}_{4}$ isotope data indicated isotopic equilibration temperatures of $360{ }^{\circ} \mathrm{C}$ to $436{ }^{\circ} \mathrm{C}$, which were close to the temperatures estimated by the chemical geothermometer based on the $\mathrm{CH}_{4} / \mathrm{CO}_{2}$ ratio when redox buffers typical of hydrothermal systems were considered (Figure 4; see Caliro et al. [2007] and Chiodini [2009] for further details). These $\mathrm{CH}_{4}-\mathrm{CO}_{2}$ equilibrium temperatures are much higher than those previously inferred in Figure 3 by Chiodini and Marini [1998], and they can be explained by the different kinetics of $\mathrm{CH}_{4}$

\section{Solfatara}

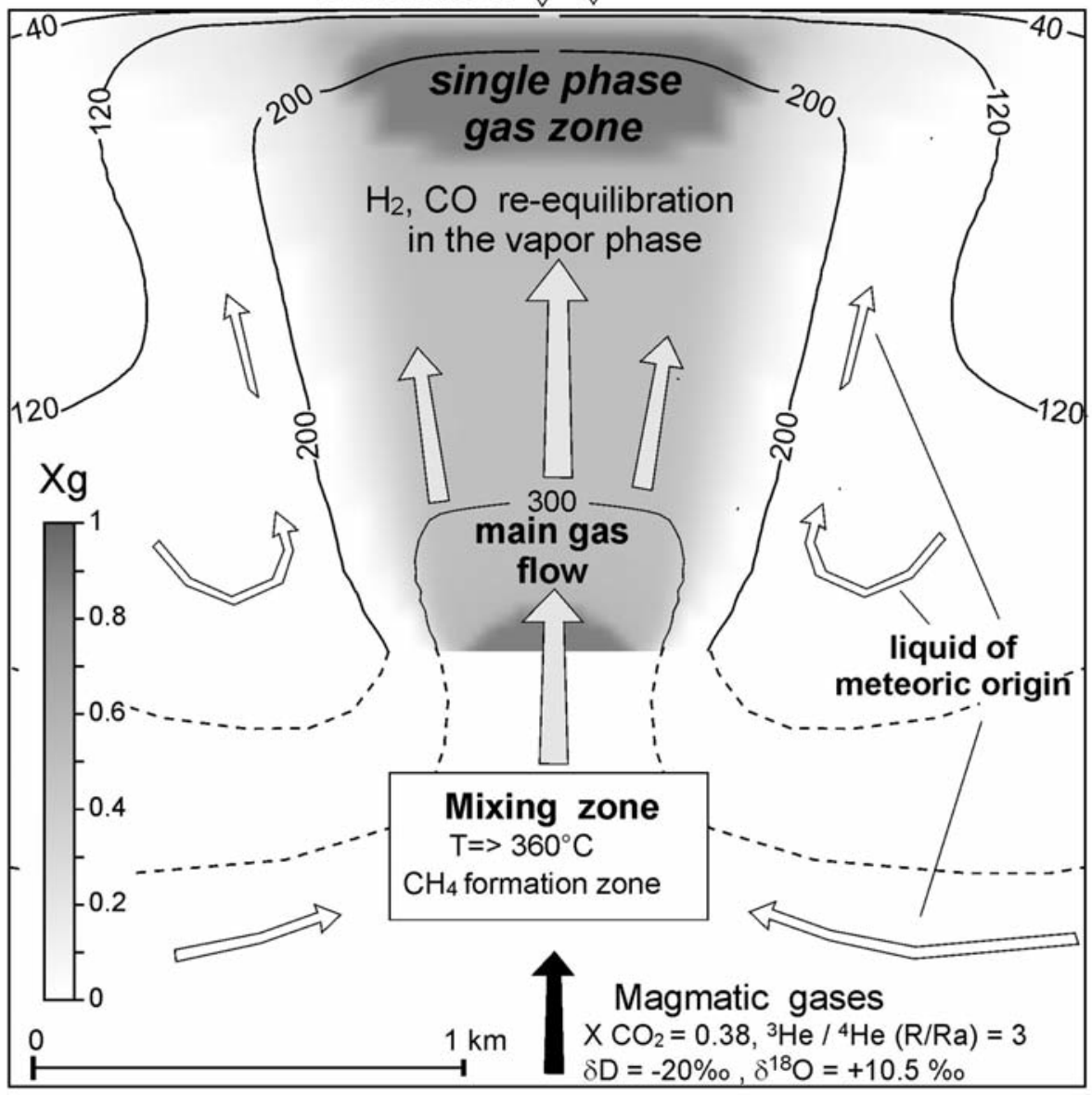

Figure 2. Revisited geochemical conceptual model of Solfatara, showing the zones of deep mixing, and $\mathrm{H}_{2}, \mathrm{CO}$ and $\mathrm{H}_{2} \mathrm{~S}$ re-equilibration in the vapor phase (after Caliro et al. 2007). The gas/liquid mass fractions (Xg), and low-temperature isotherms are shown, as arising from the physical-numerical simulations described in detail by Chiodini et al. [2003] and Todesco et al. [2003]. The gas fractions are indicated by the gray shading scale. 


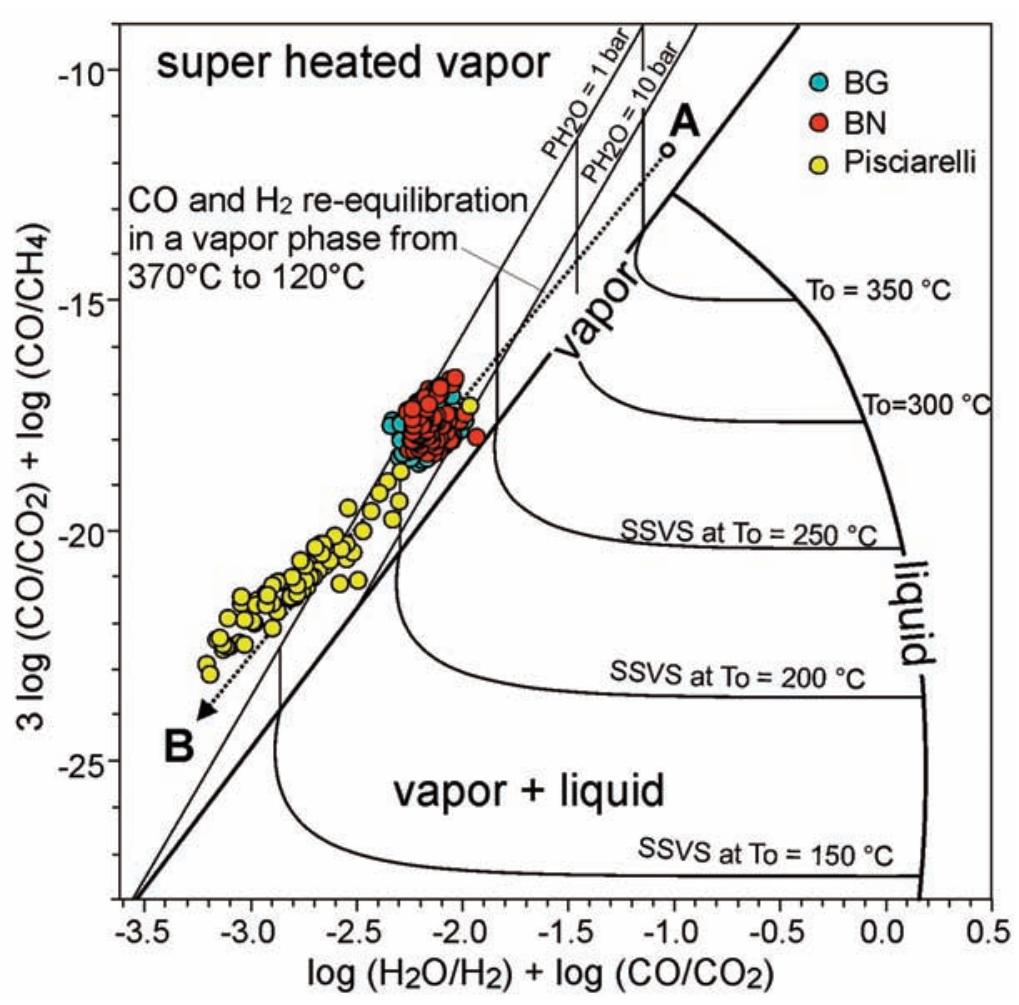

Figure 3. Theoretical values of $\log \left(\mathrm{X}_{\mathrm{H} 2 \mathrm{O}} / \mathrm{X}_{\mathrm{H} 2}\right)+\log \left(\mathrm{X}_{\mathrm{CO}} / \mathrm{X}_{\mathrm{CO} 2}\right)$ versus $3 \log \left(\mathrm{X}_{\mathrm{CO}} / \mathrm{X}_{\mathrm{CO} 2}\right)+\log \left(\mathrm{X}_{\mathrm{CO}} / \mathrm{X}_{\mathrm{CH} 4}\right)$ for a single saturated vapor phase and a single saturated liquid phase, shown as the vapor line and the liquid line, respectively. The equilibrium gas contents in a single saturated liquid phase were computed using the vapor-liquid distribution coefficient, $\mathrm{Bi}$, defined as $\mathrm{Bi}=\left(\mathrm{X}_{\mathrm{i}} / \mathrm{X}_{\mathrm{H} 2 \mathrm{O}}\right)_{\mathrm{vap}} /\left(\mathrm{X}_{\mathrm{i}} / \mathrm{X}_{\mathrm{H} 2 \mathrm{O}}\right)_{\text {liq }}$. The composition of the vapors separated in a single step at varying temperatures $\left(\mathrm{T}_{0}\right)$ (single-step vapor separation lines, or SSVS lines) and the compositions of superheated vapors equilibrated at different $\mathrm{T}-\mathrm{P}_{\mathrm{H} 2 \mathrm{O}}$ values (solid lines) are also shown. The equilibrium conditions for the high-temperature fumaroles of the Solfatara crater (BG and BN) can be inferred for a superheated vapor phase at temperatures between $200{ }^{\circ} \mathrm{C}$ and $240{ }^{\circ} \mathrm{C}$, and between $200{ }^{\circ} \mathrm{C}$ and about $150{ }^{\circ} \mathrm{C}$ for the Pisciarelli fumarole. The possible occurrence of $\mathrm{H}_{2}$ and $\mathrm{CO}$ re-equilibration upon cooling of the gas phase (see text) has also been investigated through drawing of the single gas-phase theoretical reequilibration line from $370{ }^{\circ} \mathrm{C}$ (point A) to $120^{\circ} \mathrm{C}$ (point B) under the redox conditions controlled by the buffer of D'Amore and Panichi [1980] (see the text for further details). The Solfatara compositions plot along the re-equilibration pathway, which supports the occurrence of such processes.

with respect to $\mathrm{H}_{2}$ and $\mathrm{CO}$. On the one hand, $\mathrm{CH}_{4}$, which is a species characterized by much slower kinetics than $\mathrm{H}_{2}$ and CO [Giggenbach 1987, Chiodini et al. 1993, Giggenbach 1997], does not re-equilibrate, which preserves the same concentrations as in the deepest and hottest parts of the hydrothermal system where the methane originates from $\mathrm{CO}_{2}$ reduction [Caliro et al. 2007, Chiodini 2009]. On the other hand, $\mathrm{H}_{2}$ and $\mathrm{CO}$ re-equilibrate under the decreasing temperature conditions encountered by the ascending vapor phase (Figure 2).

Apart from these theoretical considerations, the different behaviors of $\mathrm{H}_{2}$ and $\mathrm{CO}$ on the one side and of $\mathrm{CH}_{4}$ on the other are also suggested by examination of Figure 5 , where $\log \mathrm{CO} / \mathrm{CO}_{2}$ is plotted against $\log \mathrm{H}_{2} / \mathrm{H}_{2} \mathrm{O}$ (Figure 5a) and $\log \mathrm{CH}_{4} / \mathrm{CO}_{2}$ (Figure 5b). Log $\mathrm{H}_{2} / \mathrm{H}_{2} \mathrm{O}$ positively correlates with $\log \mathrm{CO} / \mathrm{CO}_{2}\left(\mathrm{r}^{2}=0.66\right)$, as expected for a vapor phase. Assuming equilibrium conditions in the vapor phase, this correlation was used to derive the oxygen fugacity $\left(\mathrm{f}_{\mathrm{O} 2}\right)$ - a temperature function that better describes the redox conditions at the Solfatara hydrothermal system:

$$
\log \mathrm{f}_{\mathrm{O} 2}=8.20+23725 / \mathrm{TK}
$$

This function was obtained by solving the following set of equations with respect to $\mathrm{f}_{\mathrm{O} 2}$ :

$$
\begin{aligned}
& \log \left(\mathrm{X}_{\mathrm{H} 2} / \mathrm{X}_{\mathrm{H} 2 \mathrm{O}}\right)=\log \left(\mathrm{X}_{\mathrm{CO}} / \mathrm{X}_{\mathrm{CO} 2}\right) \times 0.2731-1.8066 \\
& \log \left(\mathrm{X}_{\mathrm{H} 2} / \mathrm{X}_{\mathrm{H} 2 \mathrm{O}}\right)=2.548-12707 / \mathrm{TK}-1 / 2 \log \mathrm{f}_{\mathrm{O} 2} \\
& \log \left(\mathrm{X}_{\mathrm{CO}} / \mathrm{X}_{\mathrm{CO} 2}\right)=5.033-14955 / \mathrm{TK}-1 / 2 \log \mathrm{f}_{\mathrm{O} 2}
\end{aligned}
$$

where Equation (9) is the best-fit regression of the two variables (Figure 5a), while Equations (10) and (11) are the expressions of the temperature dependence of the equilibrium constants of the $\mathrm{H}_{2} \mathrm{O}$ and $\mathrm{CO}_{2}$ dissociation (reactions in Equations 1 and 2).

It is worth noting that the derived function is very similar to the $\mathrm{f}_{\mathrm{O} 2}$-TK function $\left(\log \mathrm{f}_{\mathrm{O} 2}=8.20+23643 / \mathrm{TK}\right)$ that was proposed by D'Amore and Panichi [1980] and was derived by investigating the fluids discharged by several hydrothermal systems around the World. Excluding an improbable fortuitous coincidence, this similarity suggests that the fumaroles of Solfatara are fed by a system for which the $\mathrm{H}_{2}$ and $\mathrm{CO}$ contents are controlled by typical 
hydrothermal redox conditions. In particular, the Solfatara fumaroles fall close to the equilibrium vapor line at temperatures from $130{ }^{\circ} \mathrm{C}$ to $240{ }^{\circ} \mathrm{C}$. In contrast, the log ratio $\mathrm{CH}_{4} / \mathrm{CO}_{2}$ falls far from the equilibrium values expected for the same redox and temperature conditions (Figure $5 \mathrm{~b}$ ).

This different behavior of $\mathrm{H}_{2}$ and $\mathrm{CO}$ with respect to that of $\mathrm{CH}_{4}$ in Figure 3 explains the trends of the $\mathrm{L}_{1}$ and $\mathrm{L}_{2}$ values of the Solfatara fumaroles, as highlighted by the good correlation of the measured data with the theoretical values (Figure 3, line A-B) expected for the re-equilibration of $\mathrm{H}_{2}$ and $\mathrm{CO}$ in a vapor phase that moves from a high-temperature deep zone (Figure 3, point A) to colder and shallower levels (Figure 3, point $\mathrm{B}$ ). Practically, we considered that the ratios $\mathrm{H}_{2} / \mathrm{H}_{2} \mathrm{O}$ and $\mathrm{CO} / \mathrm{CO}_{2}$ quickly readjust at the equilibrium values for redox conditions fixed by the D'Amore and Panichi [1980] empirical buffer, while the $\mathrm{CH}_{4} / \mathrm{CO}_{2}$ ratio maintains its original value of $\sim-4$ (Figure 4).

On the basis of these observations, we can conclude that $\mathrm{H}_{2}$ and $\mathrm{CO}$ are good partners for the derivation of the T-P geoindicators of the shallower parts of the hydrothermal system, while $\mathrm{CH}_{4}$ cannot be used because it reaches equilibrium conditions, if at all, under different conditions to those of $\mathrm{H}_{2}$ and $\mathrm{CO}$.

In agreement with these considerations, we considered the $\mathrm{CO}_{2}-\mathrm{H}_{2} \mathrm{O}-\mathrm{H}_{2}-\mathrm{CO}$ gas system. The equilibrium temperatures were computed by inserting the measured $\mathrm{X}_{\mathrm{H} 2 \mathrm{O}}, \mathrm{X}_{\mathrm{CO} 2}, \mathrm{X}_{\mathrm{CO}}$ and $\mathrm{X}_{\mathrm{H} 2}$ molar fractions into Equation (6), and by solving the equation with respect to temperature.

In the computation of the pressure, the fugacity coefficients were assumed to be close to unity, a reasonable assumption at relatively low pressures $(<100$ bar $)$ [Giggenbach 1980]. The pressure of the water $\left(\mathrm{P}_{\mathrm{H} 2 \mathrm{O}}\right)$ was derived using the assumption that $\mathrm{P}_{\mathrm{H} 2 \mathrm{O}}$ is fixed by the abovementioned $\mathrm{f}_{\mathrm{H} 2 \mathrm{O}}-\mathrm{T}$ relation of Giggenbach [1980] that is valid for the coexistence of vapor and liquid phases (the liquid is considered as pure water). This assumption is not based on

Figure 4 (top right). $\log \mathrm{X}_{\mathrm{CH} 4} / \mathrm{X}_{\mathrm{CO} 2}$ versus $1000 / \mathrm{TK}$ diagram. The analytical ratios for the Solfatara fumaroles are plotted against the equilibrium temperatures computed through the $\mathrm{CH}_{4}-\mathrm{CO}_{2}$ isotopic geothermometer. The theoretical ratios in a single saturated vapor phase under redox conditions controlled by the hydrothermal redox buffers [Giggenbach 1987, D'Amore and Panichi 1980] are shown for reference. The theoretical ratios expected for varying water fugacities and redox conditions fixed by the magmatic $\mathrm{SO}_{2}-\mathrm{H}_{2} \mathrm{~S}$ buffer [Giggenbach 1987] are also shown. The Solfatara fumaroles fall close to the equilibrium conditions, which supports the concept that $\mathrm{CH}_{4}$ is formed by $\mathrm{CO}_{2}$ reduction in the hydrothermal environment.

Figure 5 (bottom right). (a) Plot of $\log \left(\mathrm{X}_{\mathrm{H} 2} / \mathrm{X}_{\mathrm{H} 2 \mathrm{O}}\right)$ versus $\log \left(\mathrm{X}_{\mathrm{CO}} / \mathrm{X}_{\mathrm{CO} 2}\right)$. (b) Plot of $\log \left(\mathrm{X}_{\mathrm{CH} 4} / \mathrm{X}_{\mathrm{CO} 2}\right)$ versus $\log \left(\mathrm{X}_{\mathrm{CO}} / \mathrm{X}_{\mathrm{CO} 2}\right)$. In the diagrams, the analytical values are compared with the theoretical log ratios computed for the equilibrium vapor and liquid phases, and for the vapor phases separated in a single-step from the equilibrium liquids, at different temperatures. The theoretical grids assume that redox conditions are controlled by the $\mathrm{f}_{\mathrm{O} 2}$-buffer of D'Amore and Panichi [1980].
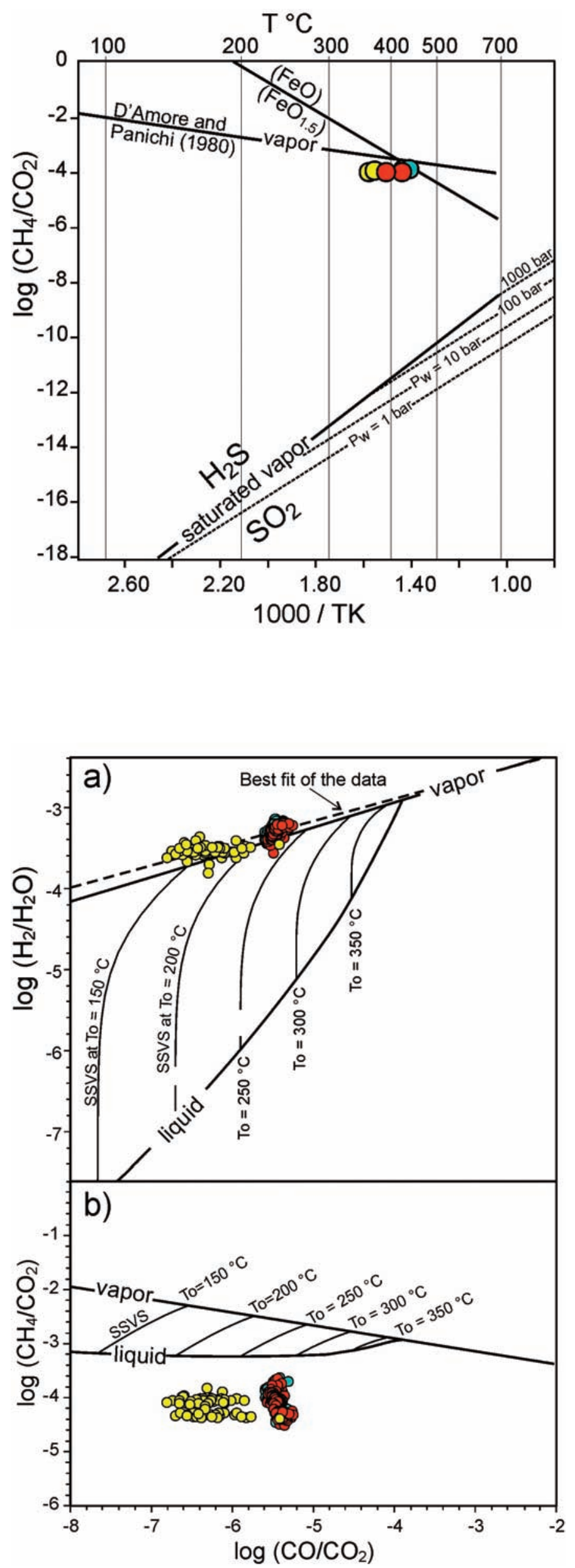
the geochemical interpretation of the data, because the $\mathrm{CO}_{2}$ $\mathrm{H}_{2} \mathrm{O}-\mathrm{H}_{2}-\mathrm{CO}$ composition indicates the presence of a vapor phase and not necessarily vapor-liquid coexistence. The vapor line in Figure 5 and the re-equilibration trend in Figure 3 are actually valid both for vapors coexisting with the liquid and for vapors with $\mathrm{P}_{\mathrm{H} 2 \mathrm{O}}$ values lower than those fixed by the presence of the liquid. The assumption is based on the results obtained by the physical numerical modeling of the hydrothermal system of Solfatara [Todesco et al. 2003] (Figure 2). The model was able to reproduce some of the main features that characterize the natural system, including the energy budget associated with the ascent and condensation of the hot fluids, and the development of a single-phase gas zone at a depth of a few hundreds of meters and at a temperature of $200{ }^{\circ} \mathrm{C}$ to $230{ }^{\circ} \mathrm{C}$ [Todesco et al. 2003] (Figure 2). The physical model returned $\mathrm{P}_{\mathrm{H} 2 \mathrm{O}}$ values close to the vapor-liquid coexistence within all of the rising fluid plume, including the single-phase gas zone. Our assumption of $\mathrm{P}_{\mathrm{H} 2 \mathrm{O}}$ fixed at any temperature by vapor-liquid coexistence is based on these results.

The pressure of $\mathrm{CO}_{2}\left(\mathrm{P}_{\mathrm{CO} 2}\right)$ was estimated on the basis of the following relation:

$$
\log \mathrm{P}_{\mathrm{CO} 2}=3.573-\log \left(\mathrm{X}_{\mathrm{H} 2} / \mathrm{X}_{\mathrm{CO}}\right)-46 / \mathrm{TK}
$$

which was derived for the $\mathrm{CO}_{2}-\mathrm{H}_{2} \mathrm{O}-\mathrm{H}_{2}-\mathrm{CO}$ gas system by Chiodini and Cioni [1989]. The temperature and pressure estimations $\left(\mathrm{P}_{\mathrm{H} 2 \mathrm{O}}, \mathrm{P}_{\mathrm{CO} 2}, \mathrm{P}_{\text {tot }}=\mathrm{P}_{\mathrm{H} 2 \mathrm{O}}+\mathrm{P}_{\mathrm{CO} 2}\right)$ are reported in Annex 1.

The equilibrium temperatures range from $195^{\circ} \mathrm{C}$ to 230 ${ }^{\circ} \mathrm{C}$ (mean, $209^{\circ} \mathrm{C}$ ), from $202{ }^{\circ} \mathrm{C}$ to $237^{\circ} \mathrm{C}$ (mean, $213^{\circ} \mathrm{C}$ ) and from $122{ }^{\circ} \mathrm{C}$ to $232{ }^{\circ} \mathrm{C}$ (mean, $157^{\circ} \mathrm{C}$ ), for the BG, BN and Pisciarelli fumaroles, respectively. The total equilibrium pressures $\left(\mathrm{P}_{\mathrm{tot}}=\mathrm{P}_{\mathrm{H} 2 \mathrm{O}}+\mathrm{P}_{\mathrm{CO} 2}\right)$ range from 17 bar to $33 \mathrm{bar}$, from 19 bar to $37 \mathrm{bar}$, and from 3 bar to $38 \mathrm{bar}$, for the BG, $\mathrm{BN}$ and Pisciarelli fumaroles, respectively. The large variations of the apparent $\mathrm{T}-\mathrm{P}$ equilibrium values estimated at Pisciarelli, which are possibly caused by secondary processes, will be discussed in more detail in the next section. It is worth noting that the average estimation performed for the two hottest fumaroles of the area, as BG and BN ( $T, \sim 210$ ${ }^{\circ} \mathrm{C}$; P, $\sim 25$ bar), practically coincide with the T-P conditions of the "single gas-phase zone" arising from the physical simulations of the system [Todesco et al. 2003] (Figure 2). We can thus consider that the variations in the time of the equilibrium $\mathrm{T}-\mathrm{P}$, which are discussed in the next section, are in some way representative of this large gas zone, which according to the simulation results, is located at a shallow depth (100-300 $\mathrm{m})$ in the subsoil of the area.

\section{Time series of the equilibrium temperatures and pressures from 1998 to 2010}

The time series of the equilibrium $\mathrm{P}-\mathrm{T}$ values recorded at the Pisciarelli fumarole are discussed separately from those computed at the BG and BN fumaroles.

\subsection{The Pisciarelli fumarole}

In recent years, the fumarolic field of Pisciarelli has experienced an evident increase in activity, which has been marked by temperature increases, by the opening of new vigorous vents and boiling pools, and by the occurrence of seismic activity localized in the area [D'Auria et al. 2011] (Figure 6).

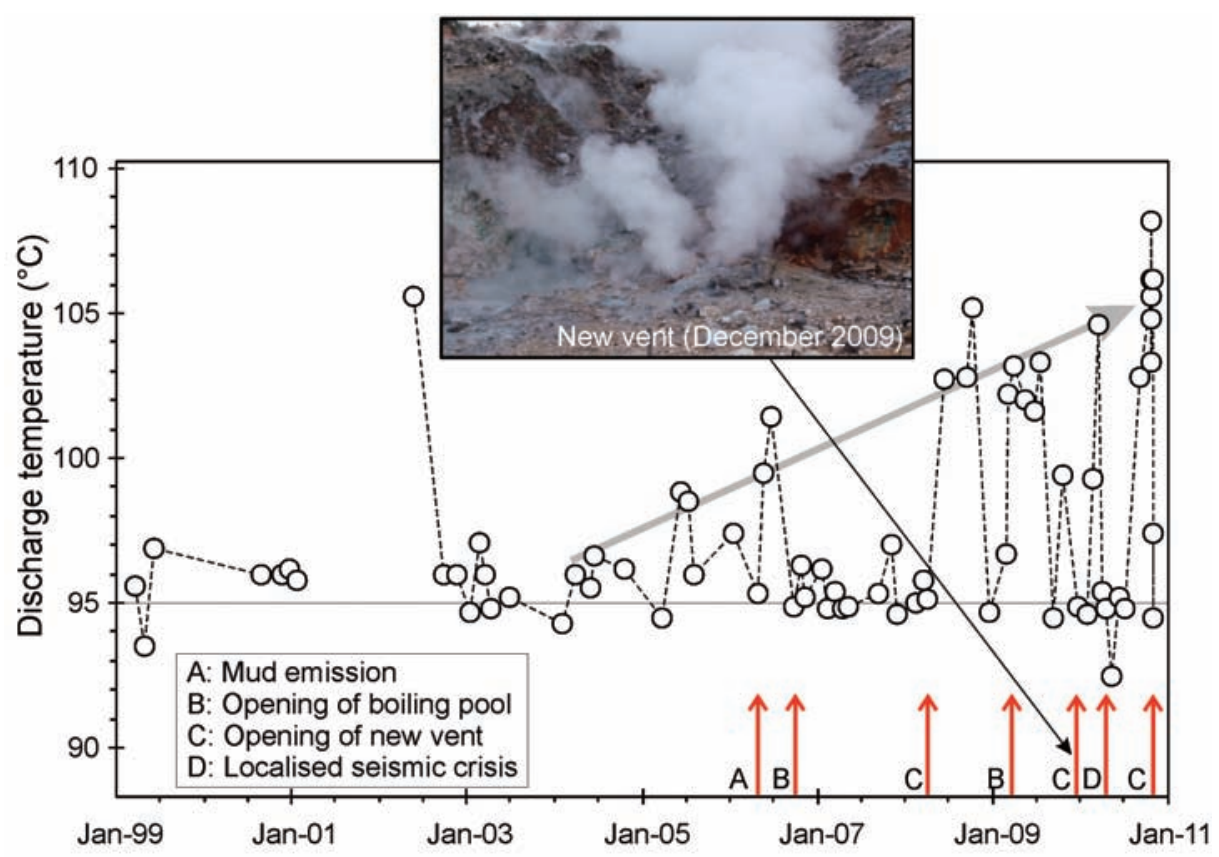

Figure 6. (a) Chronogram of the discharge temperature $\left({ }^{\circ} \mathrm{C}\right.$ ) of the Pisciarelli fumarole with the chronological occurrence of the main events (as indicated) linked to the increasing activity. The temperature of $95^{\circ} \mathrm{C}$ is the boiling temperature for the fumarolic fluids. (b) Photograph of the new roaring fumarole established on December 20, 2009. 
Figure 6 shows the fumarolic discharge temperatures together with the chronological occurrences of the main macroscopic events that have occurred at Pisciarelli since 1999. The discharge temperature from 1999 to 2005 has fluctuated around $95{ }^{\circ} \mathrm{C}$, the boiling temperature of the fumarolic fluids, with the exception of a sample in May 2002 that for the first time showed a temperature of $105^{\circ} \mathrm{C}$. After this period, and following an anomalous mud emission from the vent (April 2006), the temperature increased up to $102^{\circ} \mathrm{C}$ in June 2006, and dropped down after the occurrence (on 23 October 2006) and establishment of a new boiling pool. An enlargement of the fumarolized area and the opening of a new vent occurred in March 2008. A new increase in the temperature occurred in June $2008\left(103{ }^{\circ} \mathrm{C}\right)$, and excluding a few short periods, since then the discharge temperature has shown an increasing trend, which reached $108^{\circ} \mathrm{C}$ in October 2010. Over this period, events have occurred closer in time: the opening of a new boiling pool in March 2009, which was probably accompanied by a small explosion (mud covered the soil slope up to 3-4 $\mathrm{m}$ above the emission point), with the $\mathrm{CO}_{2}$ flux from this pool estimated at 15 ton $/ \mathrm{d}$ to $20 \mathrm{ton} / \mathrm{d}$ by the injection into the pool of a tracer gas at different (known) flow rates, and the measurement of its relative concentration with respect to the $\mathrm{CO}_{2}$ in the plume; the establishment on 20 December 2009 of a new vigorous, roaring fumarole (Figure 6), which represents the strongest gas emission of the entire area to date; the recording of a seismic swarm (of about 190 events) in the Pisciarelli area on 30 March 2010; and the opening of a new vent on 15 November 2010.

In spite of this macroscopic evidence of increasing activity, the T-P geoindicators have not given clear signals, because they have been masked by seasonal effects. In particular, an annual variation affects the fumarolic $\mathrm{CO}$ content, and consequently also the temperature and pressure estimations (Figure 7). As an example, the annual cycle is evident in Figure 8, where the equilibrium temperature is plotted against the month of sampling. The lowest temperatures, which are generally from $120{ }^{\circ} \mathrm{C}$ to $150{ }^{\circ} \mathrm{C}$, characterize the winter months, while the highest temperatures, from $150{ }^{\circ} \mathrm{C}$ to $200{ }^{\circ} \mathrm{C}$, are typical of the summer months. Similar behavior characterizes the equilibrium pressure values (Figures $7 \mathrm{~b}$ and $6 \mathrm{c}$ ). These seasonal variations might be caused by different process. A real temperature decrease might occur during the winter because of the arrival of cold meteoric water in the upper part of the feeding system. However, this is improbable, because it would imply concurrent increases in the water contents of the fumaroles and variations in the isotopic signatures of the steam; such variations are not actually observed (unpublished data, INGV - Osservatorio Vesuviano). Another explanation is that the fumarolic CO content is in some way affected by the condensation of the

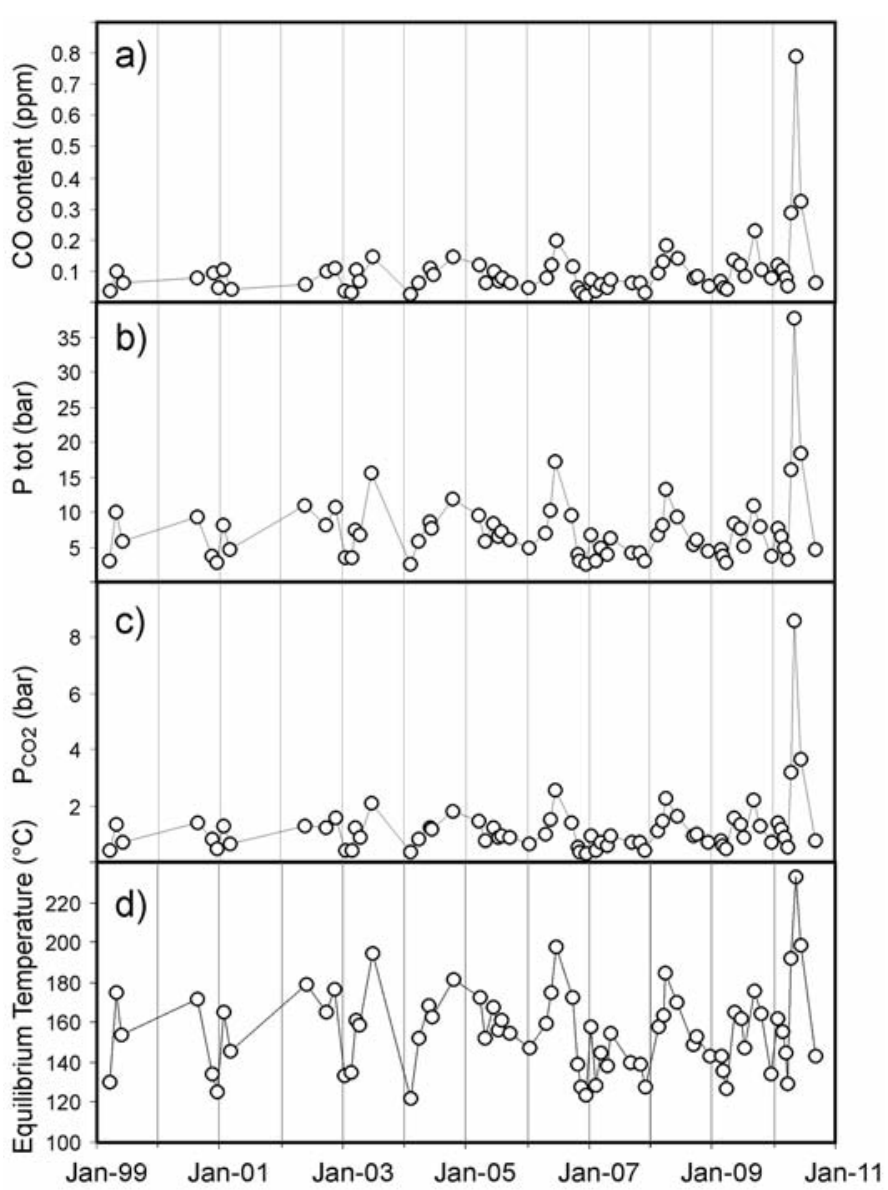

Figure 7. Chronograms of $\mathrm{CO}$ content (a), $\mathrm{P}_{\text {tot }}(\mathrm{b}), \mathrm{P}_{\mathrm{CO} 2}$ (c), and equilibrium temperature (d) for the Pisciarelli fumarole. Seasonal effects affect the fumarolic CO content and consequently the T-P estimations. It is worth noting the peak $\mathrm{CO}$ contents and $\mathrm{T}-\mathrm{P}$ estimates relative to summer 2010, when the values estimated approached those of the BG and BN fumaroles.

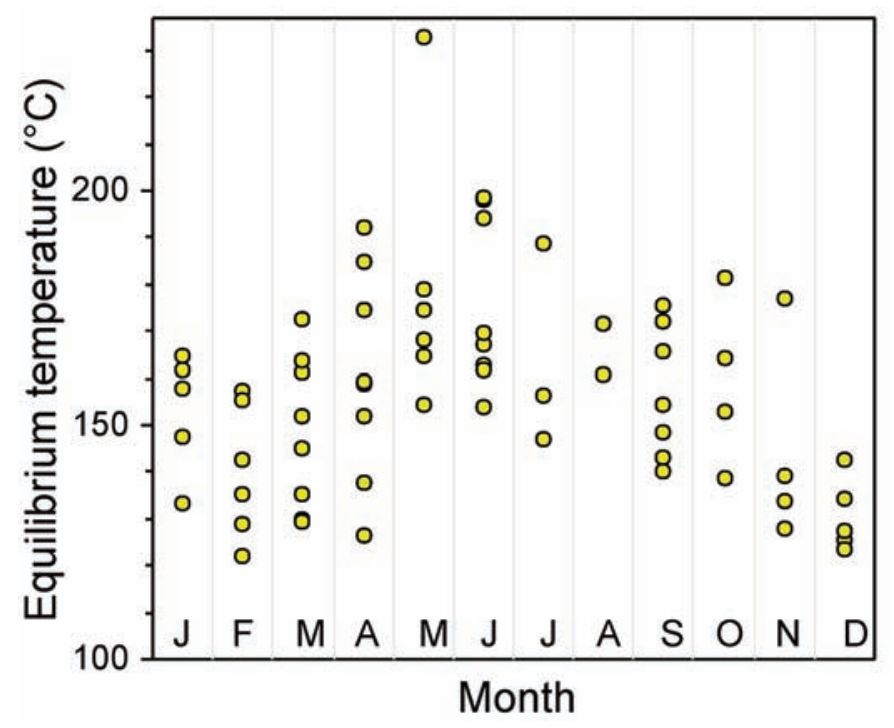

Figure 8. Equilibrium temperature of the Pisciarelli fumarole versus the month of sampling. Maximum estimated values characterize the spring and summer samples, indicating strong seasonal effects. 


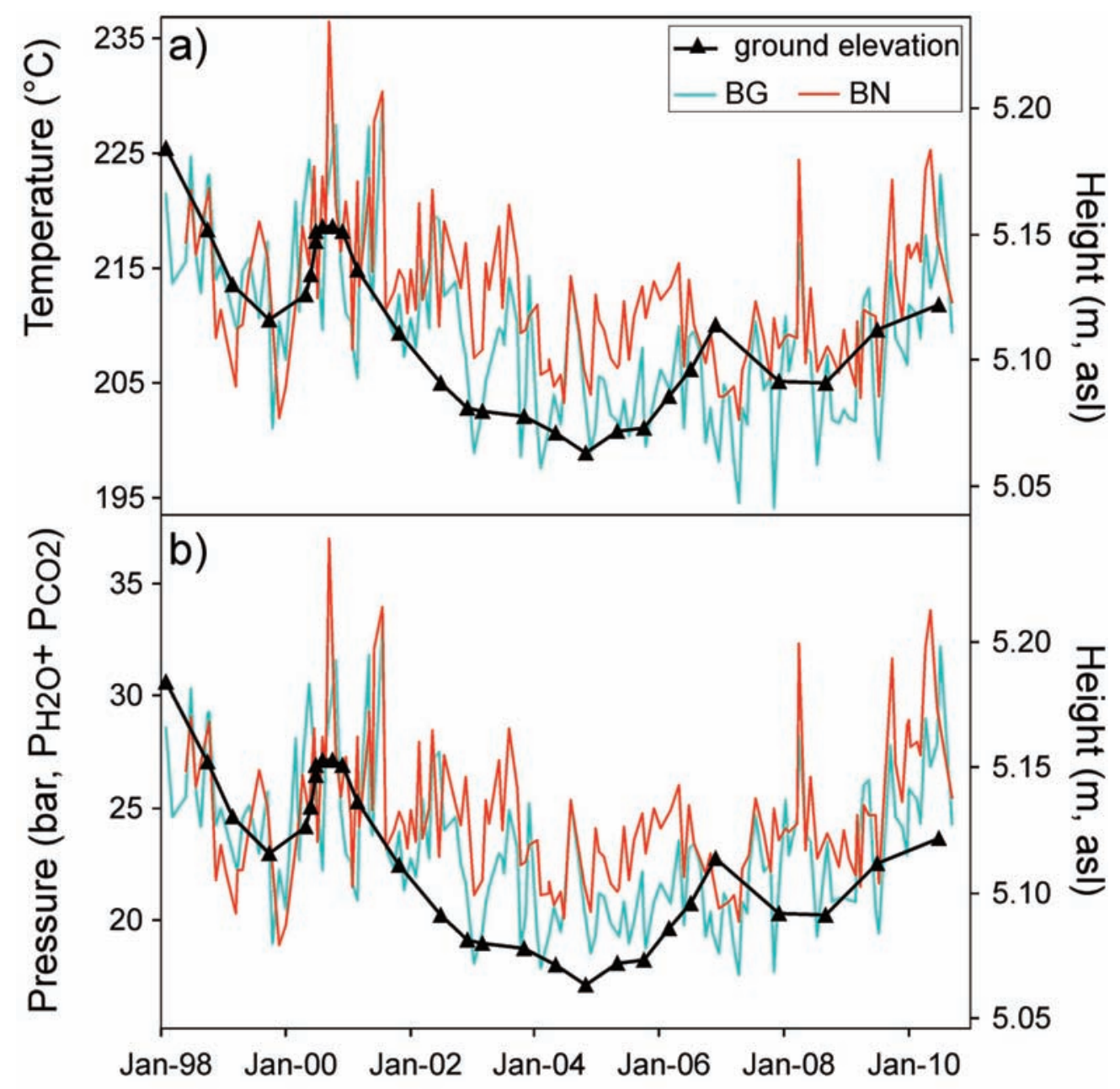

Figure 9. Chronogram of vertical ground displacement, as recorded at benchmark 25 (in Pozzuoli) and temperature (a) and pressure(b) for the BG and BN fumaroles. The similar shapes of the geochemical signals and the ground elevation suggest a possible relationship between them.

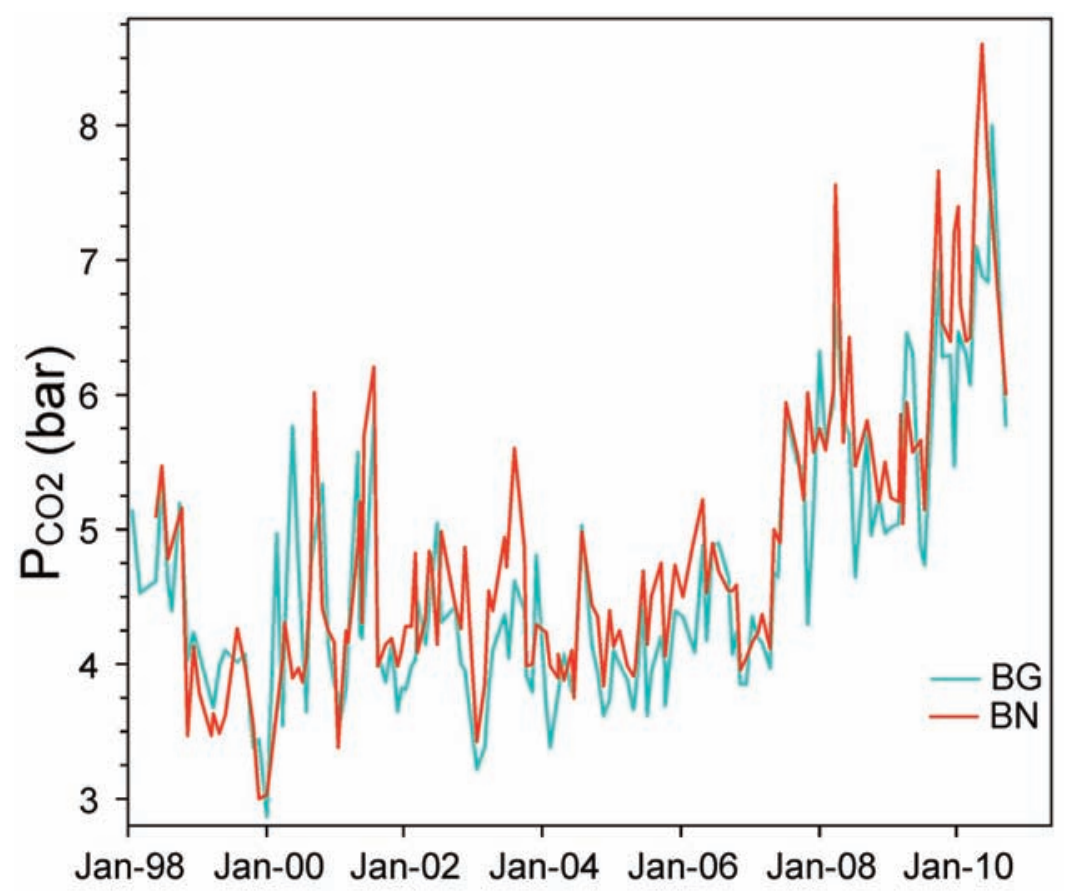

Figure 10. Chronogram of the $\mathrm{P}_{\mathrm{CO} 2}$ estimated at the $\mathrm{BG}$ and $\mathrm{BN}$ fumaroles. Since 2007, an increase in the values has been observed, and this pressurization process is still ongoing. 
fumarolic fluids, a process that is linked to the ambient temperature and that is consequently characterized by a seasonal cycle. Whatever the cause is, the data from Pisciarelli that are heavily modified by this seasonal cycle are not useful for investigations into the eventual variations caused by volcanic processes. The only sign that appears to be linked to the increased fumarolic activity is the anomalous peak of CO content in the spring to summer in 2010. Over this period, the estimated $\mathrm{T}-\mathrm{P}$ conditions increased to the highest values recorded over the last 10 years $\left(\mathrm{T}=230{ }^{\circ} \mathrm{C}\right.$, $\mathrm{P}_{\text {tot }}=38 \mathrm{bar}$, and $\mathrm{P}_{\mathrm{CO} 2}=9 \mathrm{bar}$; Figure $7 \mathrm{~b}-\mathrm{d}$ ), which are close to the values estimated for the $\mathrm{BG}$ and $\mathrm{BN}$ fumaroles.

\subsection{The $B G$ and $B N$ fumaroles}

The data from the BG and BN fumaroles are thus more interesting, as they do not show seasonal effects. In this case, the discharge temperatures are above the condensation temperature, and in contrast to the Pisciarelli site, the environment is dry, which potentially prevents important secondary processes. The chronograms of Figure 9 compare the ground elevation of the area with the equilibrium temperatures (Figure 9a) and pressures (Figure 9b) recorded from 1998 to 2010. Figure 9 highlights the good fit between the geochemical signals and the ground elevation: the initial period of subsidence from 1998 to 2000 was accompanied by a T-P decrease; the crisis of 2000 caused a positive peak in both the elevation and T-P conditions; the subsequent period from 2001 to 2004-5 was characterized by subsidence and a contemporary decrease in the T-P values; and finally, since 2004-2005, an uplift phase has started that has been accompanied by a T-P increase.

Finally, Figure 10 shows the chronogram of the equilibrium $\mathrm{P}_{\mathrm{CO} 2}$ estimated at the $\mathrm{BG}$ and $\mathrm{BN}$ fumaroles. These values were recorded in both of the fumaroles and they were relatively constant (4-5 bar) until 2006. After this, the values started to increase, and they reached the maximum of $\sim 7$ bar for the last samples of 2010. This increase in $\mathrm{P}_{\mathrm{CO} 2}$, which is a process that at the moment is still ongoing, is most probably being caused by the arrival of deep gases that have $\mathrm{CO}_{2}$ contents that are higher that those of 1998 to 2006.

\section{Conclusions}

The general considerations regarding the kinetics of the redox-sensitive gas species and the mass of analytical data indicate that $\mathrm{H}_{2}$ and $\mathrm{CO}$ are good partners for the derivation of reliable gas-geoindicators of the T-P conditions of the upper parts of Solfatara hydrothermal systems. This method was applied at the two main fumarolic fields of Solfatara: the Pisciarelli and the BG-BN sites.

At Pisciarelli, strong seasonal effects and the possibility of re-equilibration of the fumarolic fluids at very shallow depths cover the deep geothermo-barometric signals.
However, it is in this area that the signs of the increased activity are more evident. Over the last few years, the main evidence has been the increase in the discharge temperature, the opening of new vigorous vents and boiling pools, and the occurrence of localized seismic activity [D'Auria et al. 2011] (Figure 6). The only geothermo-barometric sign that appears to be linked to this increased fumarolic activity was an anomalous peak of $\mathrm{CO}$ content that was observed in the samples of summer 2010, when the equilibrium T-P reached its maximum values $\left(\mathrm{T}=230^{\circ} \mathrm{C} ; \mathrm{P}_{\text {tot }}=38\right.$ bar; and $\mathrm{P}_{\mathrm{CO} 2}=9$ bar, which approached those of the $\mathrm{BG}$ and $\mathrm{BN}$ fumaroles.

Gas geoindicators applied to the BG and BN hightemperature fumaroles generally indicate $\mathrm{T}-\mathrm{P}$ conditions $\left(\mathrm{T}=195-237^{\circ} \mathrm{C} ; \mathrm{P}_{\text {tot }}=17-37 \mathrm{bar}\right)$ that are close to those independently simulated by the application of a physical numerical approach [Todesco et al. 2003] for the shallow single-phase gas zone that constitutes the upper part of the Solfatara hydrothermal system (Figure 2). The variation in the equilibrium T-P values with time has resembled the ground movement at Campi Flegrei over the entire period of observation (1998-2010). This evident correlation between ground movement and geochemical signals supports the concept that the last uplift episodes occurred with active processes of pressurization of the shallower parts of the hydrothermal system. In particular, this process of uplift and fluid-pressure increases at shallow depths has been evident since 2006, and it is still ongoing. This probably caused the observed macroscopic increases in the hydrothermal activities at Pisciarelli, and if it continues with time, this might lead to more critical conditions, including the possible occurrence of phreatic explosions.

Acknowledgements. The authors are grateful to Salvo Inguaggiato and to an anonymous reviewer, for their useful comments and suggestions for the early version of this manuscript.

\section{References}

Barberi, F., D.P. Hill, F. Innocenti, G. Luongo and M. Treuil (1984). On the 1982-1984 bradyseismic crisis at Phlegraean Fields (Italy), Bull. Volcanol., 47, 171-411.

Caliro, S., G. Chiodini, R. Moretti, R. Avino, D. Granieri, M. Russo and J. Fiebig (2007). The origin of the fumaroles of La Solfatara (Campi Flegrei, South Italy), Geochim. Cosmochim. Acta, 71, 3040-3055; doi: 10.1016/j.gca.2007. 04.007.

Cardellini, C., G. Chiodini and F. Frondini (2003). Application of stochastic simulation to $\mathrm{CO}_{2}$ flux from soil; mapping and quantification of gas release, J. Geophys. Res., 108 (B9), 2425; doi: 10.1029/2002JB002165.

Chiodini, G. and R. Cioni (1989). Gas barometry for hydrothermal systems and its application to some Italian geothermal areas, Appl. Geochem., 4, 465-472.

Chiodini, G., R. Cioni, M. Guidi, L. Marini, B. Raco and G. Taddeucci (1992). Gas geobarometry in boiling hydro- 
thermal systems: a possible tool to evaluate the hazard of hydrothermal explosions, Acta Vulcanol., 2, 99-107.

Chiodini, G., R. Cioni, L. Marini, B. Raco and G. Taddeucci (1993). Vulcano and Stromboli; gas geochemistry; fumarolic gases geochemistry, Acta Vulcanol., 3, 280-282.

Chiodini, G., R. Cioni, G. Magro, L. Marini, C. Panichi, B. Raco and M. Russo (1996). Chemical and isotopic variations of Bocca Grande fumarole (Solfatara Volcano, Phlegrean Fields), Acta Vulcanol., 8, 129-138.

Chiodini, G. and L. Marini (1998). Hydrothermal gas equilibria: The $\mathrm{H}_{2} \mathrm{O}-\mathrm{H}_{2}-\mathrm{CO}_{2}-\mathrm{CO}-\mathrm{CH}_{4}$ system, Geochim. Cosmochim. Acta, 62, 2673-2687.

Chiodini, G., R. Cioni, M. Guidi, G. Magro, L. Marini, C. Panichi, B. Raco and M. Russo (2000). Vesuvius and Phlegrean Fields; gas geochemistry; geochemical monitoring of the Phlegrean Fields and Vesuvius (Italy) in 1996, Acta Vulcanol., 12, 117-119.

Chiodini, G., F. Frondini, C. Cardellini, D. Granieri, L. Marini and G. Ventura (2001). $\mathrm{CO}_{2}$ degassing and energy release at Solfatara Volcano, Campi Flegrei, Italy, J. Geophys. Res., 106, 16213-16221.

Chiodini, G., M. Todesco, S. Caliro, C. Del Gaudio, G. Macedonio and M. Russo (2003). Magma degassing as a trigger of bradyseismic events; the case of Phlegrean Fields (Italy), Geophys. Res. Lett., 30, 1434; doi: 10.1029/2002GL016790.

Chiodini, G. (2009). $\mathrm{CO}_{2} / \mathrm{CH}_{4}$ ratio in fumaroles: a powerful tool to detect magma degassing episodes at quiescent volcanoes Geophys. Res. Lett., 36, L02302; doi: 10.1029/2008GL036347.

Cioni, R. and E. Corazza (1981). Medium-temperature fumarolic gas sampling, Bull. Volcanol., 44, 23-29.

Cioni, R., E. Corazza and L. Marini (1984). The gas/steam ratio as indicator of heat transfer at the Solfatara fumaroles, Phlegraean Fields (Italy), Bull. Volcanol., 47, 295-302.

Cioni, R., E. Corazza, M. Fratta, M. Duidi, G. Magro and L. Marini (1989). Geochemical precursors at Solfatara Volcano, Pozzuoli (Italy), Springer-Verlag, Berlin.

D'Amore, F. and C. Panichi (1980). Evaluation of deep temperatures of hydrothermal systems by a new gas geothermometer, Geochim. Cosmochim. Acta, 44, 549-556.

D'Auria, L., F. Giudicepietro, I. Aquino, G. Borriello, C. Del Gaudio, D. Lo Bascio, M. Martini, G.P. Ricciardi, P. Ricciolino and C. Ricco (2011). Repeated fluid-transfer episodes as a mechanism for the recent dynamics of Campi Flegrei caldera (1989-2010), J. Geoph. Res., in press; doi: 10.1029/2010JB007837.

Del Gaudio, C., I. Aquino, G.P. Ricciardi, C. Ricco and R. Scandone (2010). Unrest episodes at Campi Flegrei: A reconstruction of vertical ground movements during 1905-2009, J. Volcanol. Geotherm. Res., 195, 48-56.

Dvorak, J. J. and G. Mastrolorenzo (1991). The mechanisms of recent vertical crustal movements in Campi Flegrei Caldera, southern Italy, Special Paper - Geological Soci- ety of America, 263, 47.

Giggenbach, W.F. (1975). A simple method for the collection and analysis of volcanic gas samples, Bull. Volcanol., 39, 132-145.

Giggenbach, W.F. (1980). Geothermal gas equilibria, Geochim. Cosmochim. Acta, 44 (12), 2021-2032.

Giggenbach, W.F. (1987). Redox processes governing the chemistry of fumarolic gas discharges from White Island, New Zealand, Appl. Geochem., 2 (2), 143-161.

Giggenbach, W.F. and R.L. Goguel (1989). Collection and analysis of geothermal and volcanic water and gas discharges, Department of Scientific and Industrial Research, Chemistry Division, Petone, New Zealand.

Giggenbach, W.F. (1997). The origin and evolution of fluids in magmatic-hydrothermal systems, In: Barnes, H.L. (ed.), Geochemistry of Hydrothermal Ore Deposits, John Wiley \& Sons Inc., 737-796.

Horita, J. (2001). Carbon isotope exchange in the system $\mathrm{CO}_{2}$ $\mathrm{CH}_{4}$ at elevated temperatures, Geochim. Cosmochim. Acta, 65 (12), 1907-1919.

Orsi, G., S. DeVita and M. diVito (1996). The restless, resurgent Campi Flegrei nested caldera (Italy): constraints on its evolution and configuration, J. Volcanol. Geotherm. Res., 74, 179-214.

Todesco, M., G. Chiodini and G. Macedonio (2003). Monitoring and modelling hydrothermal fluid emission at $\mathrm{La}$ Solfatara (Phlegrean Fields, Italy); an interdisciplinary approach to the study of diffuse degassing, J. Volcanol. Geotherm. Res., 125, 57-79.

Troise, C., G. De Natale, F. Pingue, F. Obrizzo, P. De Martino, U. Tammaro and E. Boschi (2007). Renewed ground uplift at Campi Flegrei caldera (Italy): new insight on magmatic processes and forecast., Geophys. Res. Lett., 34, L03301; doi: 10.1029/2006GL028545.

*Corresponding author: Giovanni Chiodini,

Istituto Nazionale di Geofisica e Vulcanologia, sezione di Napoli, Osservatorio Vesuviano, Naples, Italy;

e-mail: giovanni.chiodini@ov.ingv.it.

C 2011 by the Istituto Nazionale di Geofisica e Vulcanologia. All rights reserved. 